\title{
PROFESSIONAL CORPORATIONS
}

\author{
M. C. RODNEY*
}

\begin{abstract}
Legisiation in Alberta prohibits practically all major professions from carrying on their busilless in corporate form. The result is that these groups labor under substantial tax disadvantages. The author, after discussing the American progress in this area. concludes that a Professional Corporations Act is necessary if this disparity of taxation is to be removed. He suggests provisions which would require specific treatment in such a statute.
\end{abstract}

Existing legislation in the Province of Alberta prohibits, either expressly or by implication, all of the major professions, with the sole exception of engineering, geology and geophysics,' from carrying on business in corporate form and it has only been within the last year or so that there has finally begun to emerge a rapidly developing interest in professional incorporation. The underlying reasons for this sudden surge in interest (which is not confined to this Province alone) are two-fold; first and foremost is the disparity in tax treatment which exists between the self-employed and the company and secondly, there is the growing concern as to the consequences of unlimited liability.

It is only natural that as the burden of taxation steadily increases the professions should become increasingly dissatisfied with the numerous tax advantages which are made available only to the business which is conducted in corporate form. There really is no satisfactory answer to the complaint of the self-employed professional man that while his income is taxed at graduated rates which soon exceed $50 \%$, the income of the business conducted in corporate form is taxed at the rate of $21 \%$ on the first $\$ 35,000.00$ and at $50 \%$ on any excess. Likewise, how can one logically justify the inability of the self-employed to establish a registered pension plan or profit sharing plan for himself, his co-partners and employees.

As the complexity of current business techniques increases, as current damage awards grow larger and as professional liability insurance becomes both more expensive and more difficult to obtain one cannot help but sympathize with the lawyer, the accountant and the doctor who are becoming increasingly concerned with the possibility of complete financial ruin because of the negligence of a co-partner or even an employee.

There are other subsidiary advantages which result from the incorportation of a professional practice; some of these are: (a) provision is made for continuity of the practice by successors (b) more satisfactory provision is made for the withdrawal, retirement or addition of associates (c) provision is made for more effective management of the practice (d) buy-sell agreements between associates are easier both to prepare and implement.

It is against this background, then, that the potential role of the professional corporation in the conduct of a professional practice must be examined.

- B.C.L. (McGili) of the Edmonton firm of Clement. Parlee, Irving. Mustard \& Rodney.

1 The Engineering and Related Professions Act. S.A. 1960. c. 26, S. 19(1). 
The disparity in tax treatment can be removed in one of two ways. Either the revenue authorities in Ottawa must be persuaded to make the appropriate amendments to the Income Tax Act or alternatively the provincial legislature must be persuaded to enact the necessary legislation so as to permit the practice in corporate form. Unfortunately it is extremely doubtful that representations made to Ottawa would meet with an early result, so that the only practical approach appears to be the provincial legislature.

The removal of unlimited liability likewise requires provincial legislation, but at the moment it is difficult to state with any degree of certainty whether or not it is realistic to expect any substantial degree of relief in this area.

Any assessment of the potential role of the professional corporation in Canada must include an examination of its history in the United States, where many of the States have already passed the necessary legislation. One may not be altogether surprised to learn that this is a history of incessant conflict between the professions and the Internal Revenue Service, because the real impetus behind the drive for professional incorporation was primarily in order to obtain equality of tax treatment between self-employed professionals and businesses conducted in corporate form.

The Internal Revenue Code" has, for many years," contained a detailed definition of a "corporation" for tax purposes. A corporation is defined as including not only the artificial entity but also associations, joint stock companies, insurance companies and certain types of trusts. The original purpose of this definition was to tax various organizations which had most of the corporate characteristics except a charter.

In 1935 the leading case of Morrissey v. Commissioner' set forth the characteristics, which, if possessed by an organization, would cause it to fall within the Internal Revenue Code definition of a corporation. These characteristics were listed as follows: (1) associates; (2) the objective of carrying on business and dividing profits; (3) continuity of life; (4) centralized management; (5) limited liability for the debts of the organization; (6) free transferability of interests in the organization. The necessity for these characteristics was subsequently affirmed in a number of decisions including United States v. Kinter."

As a result of the Morrissey decision a number of forward looking professional men, apparently primarily doctors, attempted, with some degree of success to form associations for the conduct of their practice which contained a sufficient number of the required characteristics so as to qualify as a corporation under the Internal Revenue Code but which would not offend the State prohibition against the practice in corporate form.

Thus we see that, as so often happens in this country, legislation which was originally introduced for the purpose of enlarging the laxation net was employed by the taxpayer for the purpose of opening up holes in the same net.

The next move was made by the Commissioner of Internal Revenue 
in November of 1960 when he passed regulations under Section 7701 of the Internal Revenue Codc.';

These regulations, which followed very closely the characteristics outlined in the Kinter decision (and thus soon became known as the Kinter Regulations). stated that in order for a partnership to be classified as a corporation for tax purposes it must possess, in addition to associates and the objective of carrying on business and dividing profits, at least three of the four romaining characteristics listed in the Morrissey decision.

Following the introduction of the Kinter Regulations some twenty state legislatures were prevailed upon to pass, during the period 19601962 (this was subsequently increased to some thirty-fivc), legislation which would permit varying categories of the professions to either incorporate their practice or organize associations which it was assumed at the time would comply with the Kinter Regulations.

Following the passage of this state legislation the Internal Revenue Service immediately made it known that not only would it question the professional association but that it would also question the professional corporation in order to deny both corporate status under the Internal Revenue Code. This was followed in $\mathbf{1 9 6 5}$ by further regulations: which specifically denied corporate status for tax purposes to professional corporations and associations. As a result of these actions of the Internal Revenue Service all but a few of the more enterprising professional men shied away from both the professional association and the professional corporation.

However, the ensuing battle between the enterprising few and the Internal Revenue Service has indicated to date that the Internal Revenue Service may yet lose the final round. In two recent decisions-Empey v. United States' and O'Neill v. United States"-the Courts have held the 1965 regulations to be invalid on the basis that notwithstanding the introduction of these regulations the Court is still entitled to interpret the provisions of Section 7701 of the Code as it sces fit. However, no final conclusion can be reached as to the proper tax treatment of the professional corporation in the United States until these two cases and some further twenty pending cases are finally adjudicated.

At the same time as this battle was being waged between the professions and the Internal Revenue Service, attempts werc being made to obtain at least some degree of equality of tax treatment through Congress. The Keogh Bill, which proposed a tax free deferment of a limited amount of income for retirement purposes (by permitting the self-employed to utilize existing legislation covering pension plans and profit sharing plans), failed to obtain passage in ten successive sessions of Congress prior to 1962; and it was only in 1962 that Congress was persuaded to pass a considerably watered down version of the original bill. In 1965, as a result of continuous pressure applied by the professions, certain amendments were finally made which gave to the selfemployed most of the benefits which had been available for many years to corporate employees.

it Treas. Rcg. 301-7701 (1950).

; Treas. Reg. 301. 7701-2(h).

(1967). 272 Fed. Supp. 85̃1 (D.C. Colo.1.

(1968). 281 Fed. Supp. 359 (D.C. Ohio). 
Once the state legislatures began passing the necessary legislation permitting the incorporation of professional corporations it was necessary for the legal fraternity to arrive at a conclusion on the ethical problems which would arise upon the replacement of the sole proprietorship or partnership by the professional corporation. In 1962 Opinion 303 was adopted and published by the Professional Ethics Committee of the American Bar Association. Under this Opinion, the Committee held that lawyers could carry on the practice of law as a professional association or a professional corporation with the characteristics of limited liability, centralized management, continuity of life and transferability of interest without being in violation of one or more of the Canons of Ethics, provided appropriate safeguards were observed. The Opinion concluded with these comments:

it (is) clear that it is possible for lawyers to engage in the practice of law under a form or organization that imposes limited liability without violating any of the Canons of Ethics if the following safeguards are observed,-

1. The lawyer or lawyers rendering the legal services to the client must be personally responsible to the client.

2. Restrictions on liability as to other lawyers in the organization must be made apparent to the client.

Primarily because of the uncertainties as to tax treatment and also because it was recognized that the professional incorporation constituted a departure from the traditional methods of organization, the professional corporation has to date been used sparingly by lawyers in the United States. For example in the State of Florida; out of some 10,500 lawyers only about 20 have incorporated professional corporations. Medical doctors appear to have approached the professional corporation with less trepidation than their legal brethren; in the State of Wisconsin between 12 and 15 professional corporations have been incorporated by lawyers while between 50 and 75 have been incorporated by doctors.

Turning now from this brief history of the professional corporation in the United States to its potential role in Canada, very careful consideration must be given to its tax implications under the Income Tax Act (Canada)." Answers to the following two questions are of prime importance:

(a) Will the professional corporation confer substantial tax advantages on the self-employed professional man?

(b) Can the Department of National Revenue, under existing legislation, launch an attack upon the professional corporation along the general lines of the battle being waged in the United States as outlined above?

The answer to the first question can best be answered by way of a hypothetical example. The figures used in this example are based upon 1966 tax rates and it should be noted that they assume an annual distribution of the entire net profits of the professional corporation. Obviously the amount of tax, in any year, could be deferred if a portion of the earnings were retained by the corporation.

1. Assume a partnership composed of three partners whose percentage participation in the profits is as follows,

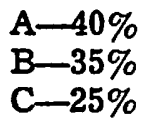

10 Income Tax Act, R.S.C. 1952, c. 148, as amended to date. 
2. Assume that the annual net income of the partnership before distributions to partners as follows:

$$
\begin{array}{r}
1967-\$ 75,000 \\
1968-\$ 80,000 \\
1969 — \$ 90,000 \\
\hline \$ 245,000
\end{array}
$$

3. The annual taxes paid by $A, B$ and $C$ (using a personal exemption figure of $\$ 2,000$ for each) over the three year period would be as follows:

\begin{tabular}{ccc} 
& Aggregate Income & Aggregate Tax \\
A & $\$ 98,000$ & $\$ 33,814$ \\
B & 85,750 & 27,726 \\
C & 61,250 & 16,494 \\
& $\$ 245,000$ & $\$ 78,034$ \\
\hline
\end{tabular}

4. Now assume that $\overline{A, B}$ and $C$ are shareholders in Company $X$ in the same proportions as their percentage interest in the above partnership and that the annual net income of Company $X$ before payment of salaries or dividends to $\mathrm{A}, \mathrm{B}$ or $\mathrm{C}$ was as set out in paragraph 2 above. Further assume that in each of the three years $A, B$ and $C$ are paid a salary by Company $X$ in such amount as will result in the net income of the Company being reduced to $\$ 35,000$ (to obtain the low corporate rate) and that in each of the three years the entire net income of the Company is distributed to its shareholders either in the form of salary or dividends with the appropriate election under section 105 . The corporate tax and the personal tax of A, B and C would be as follows:

Corporate Tax over the three year period

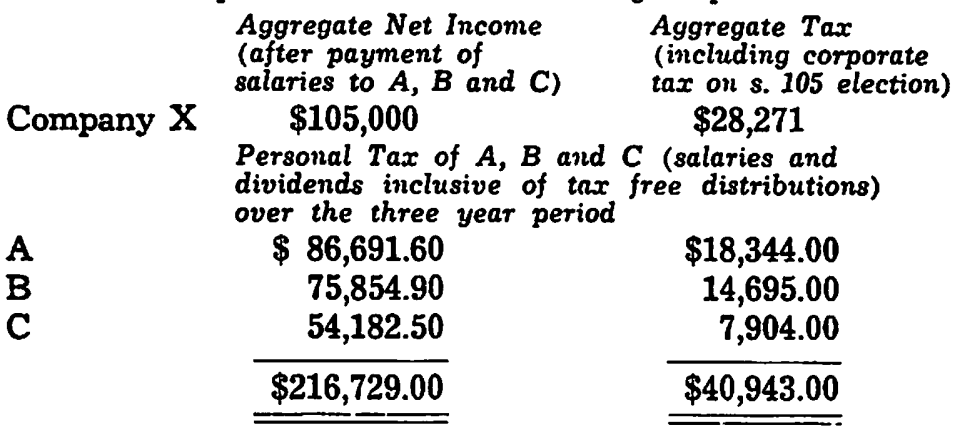

5. (a) The total personal tax of $\mathrm{A}, \mathrm{B}$ and $\mathrm{C}$ as partners would be-

(b) The total corporate and personal tax of A, B and C as shareholders would be-

$\$ 78,034.00$

$\$ 69,214.00$

(c) The tax saving over the three year period as a result of incorporation would be-

$\$ 8,820.00$

6. Consider next the income required to be earned by Company $X$ and the income required to be earned by the partnership in order to pay for an accounting machine purchased in 1969 for the sum of $\$ 5,000$.

Since Company $X$ is in the $21 \%$ tax bracket it must earn $\$ 6,330$ before taxes to provide the $\$ 5,000$ purchase price of the machine.

If partners $\mathrm{A}, \mathrm{B}$ and $\mathrm{C}$ purchased the accounting machine in proportion to their entitlement to the net profits of the partnership then: 
$A$, who had a taxable income during 1969 of $\$ 34,000$ would require an income of $\$ 4,000$ in order to pay for a 40 per cent interest in the machine; and

$\mathrm{B}$, who had a taxable income during 1969 of $\$ 29,500$ would require an income of $\$ 3,300$ in order to pay for a 35 per cent interest in the machine; and

$C$, who had a taxable income during 1969 of $\$ 20,500$ would require an income of $\$ 2,230$ in order to pay for a 25 per cent interest in the machine.

In the net result $\mathrm{A}, \mathrm{B}$ and $\mathrm{C}$ must earn approximately $\$ 9,530$ before taxes to provide the purchase price of the machine. However, it is only fair to point out that since the highest tax rates for A, B and C exceed the Company's rate of $21 \%$, the application of capital cost allowance in subsequent years would substantially offset this differential in cash outlay.

In addition to the straight tax saving which would result from professional incorporation many fringe benefits (deductible in computing corporate taxable income) would also become available to the professional who was an employee of the professional corporation; these benefits include registered pension plans, deferred profit sharing plans, group life insurance, sickness and accident and medical plans. In addition to these fringe benefits there are a number of other benefits which the Income Tax Act limits to corporations; for example section 18 can be used to reduce corporate income in high income years and at the same time a three year postponement of personal tax is available.

Unfortunately space does not permit an analysis to be made of the tax position of the professional corporation as compared to the "service company" which is so popular with the medical profession. Since, in large law firms at least, a very heavy portion of its expenses are represented by salaries paid to lawyers employed by the firm (and these lawyers cannot under existing legislation be employed by the service company) the service company cannot compare favourably with the professional corporation; furthermore registered pension plans and profit sharing plans would have no real application.

The answer to the first question must therefore be in the affirmative.

The answer to the second question requires an examination of the applicable Canadian case law (which is not too extensive) together with the provisions of section 139(1)(h) of the Income Tax Act ${ }^{11}$ which reads as follows:

(h) 'corporation' includes an incorporated company and a corporation incorporated in Canada' includes a corporation incorporated in any part of Canada before or after it became part of Canada.

While this section has never received any consideration by the Courts, one tax authority has stated that: ':

The purpose of this definition is to remove any doubt that the word 'corporation' includes any form of incorporated company. Thus the fact that the company may be one of unlimiled liability, as opposed to those the liability of whose shareholders is limited, will not disqualify it from being a corporation under this definition for the purposes of this Act.

A 1964 decision of the Exchequer Court in Kindree v. M.N.R. ${ }^{1: 5}$ is illustrative of the unsuccessful attempts of a professional man to in- 
corporate his practice notwithstanding that the relevant provincial legislation required such practice to be carried on by the individual. In this case the appellant doctor incorporated, in 1957, a private company of which he became the principal and controlling shareholder. He purported to enter into an employment contract with this company whereby he was to receive a fixed salary. Subsequent to incorporation all receipts from the medical clinic were deposited in the company's bank account from which all medical expenses were paid. The appellant reported as his income his salary received from the company. It was held that under the relevant provincial act the practice of medicine could only be carried on by a natural person which involved a personal responsibility to the client and the governing body of the profession. Thus the appellant was precluded from practising medicine as an employee of the company and in reality there was no real change in the manner in which the practice was continued subsequent to incorporation. The amount received by the company for professional services rendered by the appellant was therelore fces already earned by him and the company was merely the assignee of these fees which it did not and could not earn.

This decision indicates that the professional corporation legislation must make it clear that the professional corporation is entitled to carry on the practice of the appropriate profession in order to forestall any suggestion by the Department of National Revenue that in reality the income from the practice belongs to the shareholders (as the only persons licensed to practice) and not the corporation.

There are a number of decisions very similar to the Kindree case and they include No. 594 v. M.N.R." and Adams v. M.N.R."

However the decision of the Tax Appeal Board in Thomas Lamb v. M.N.R." indicates that legislation specifically permitting the incorporation of a profession will require the Department of National Revenue to tax the professional fees as corporate income. In this case a professional engineer, resident in Calgary, incorporated in 1958 under the Companies Act of Alberta a private company to carry on his practice. All the company shares were held by the appellant except for a few qualifying shares allotted to his wife. The company conducted the practice of engineering and paid the appellant a salary. The appellant reported as income his salary and directors fees but the Minister took the position that the company existed in name only and proceeded to assess the appellant on the total fees received by the Company. The appeal was allowed on the basis that the fees were income of the company and not the appellant. This case was distinguished from the No. 594 and Adams cases on the basis that a right was granted by a provincial statute for a corporation to practice engineering in its own name. Unlike the other two cases there was no assignment of income to the company after it had been earned by the appellant.

In view of the very broad definition of the word "corporation" contained in the Income Tax Act and in the light of the decisions referred to above it seems that (subject to the caveat appended to the discussion of the Kindree decision) the answer to the second question 
must be that there is very little likelihood that the Department of National Revenue could launch a serious attack on the Canadian professional corporation in an attempt to deny it corporate status under the Act.

The 1967 Interim Report of the Ontario Select Committee on Company Lawii discussed briefly the potential role of the professional corporation; after noting that "under existing law, very real income tax advantages ... would accrue to the professional person or partnership on incorporation of the practice" the resultant ethical problems were dealt with as follows:

2.2.5. Not a few of the objections to permitting an incorporated professional practice seemed to relate to specific relatively minor problems which are said to arise from permitting the incorporated practice, for example, should the directors and shareholders all be requircd to be licensed practioners of the particular profession? The main objection of substance to permitting incorporated professional practices seems to be the apprehension of professional associations and licensing bodies that once the professional man is cloaked with the corporate form, the professional relationship between the professional and his patient or client will be impaired, if not severed, thus resulting in detriment to the public generally.

2.2.6. On balance, the Committee has concluded that the objections to incorporating the professional practice are unfounded and the Committee therefore recommends that the Ontario Act be amended by adding as a new Part a code of rules designed to permit the incorporation of professional service companies. It seems unrealistic to prohibit medical, legal, accounting and architectural practices, for example, from being carried on in incorporated form when at the present time such practices are in fact carried on, in some cases, in very large partnerships.

2.2.8. The Committee is of the opinion that incorporation of the professional practice should not detract from the professional nature, attitudes and ethics of the profession; nor should incorporation mean that the professional practice would erode the valuable and traditional relationship presently existing between the professional man and his clients or patients.

Because of the special restrictions which would have to be made applicable to the professional corporation it would not be possible to permit incorporation under the existing Companies Act of this Province although many provisions of that Act could be made applicable following its incorporation.

In the United States nearly every State which permits the incorporation of one or more of the professions has enacted a special Professional Corporations Act which applies to all the applicable professions and in many instances this same act makes applicable to the professional corporation various provisions which are contained in existing company legislation governing the conventional business corporation. This method clearly seems to be the most satisfactory way of enacting the necessary legislation and it is recommended that it be adopted by this Province.

The following is a brief discussion of some of the more important provisions which would require specific treatment in a Professional Corporations Act of Alberta.

1. Those professions to which the Act would apply could be listed in a schedule thus facilitating the making of additions to or deductions from that list.

2. Restrictions would have to be imposed upon the name of the professional corporation. In the United States most statutes require the corporate name to end with such designations as "Professional Corpo-

17 Chap. II, Sec. 2. 
ration" or the abbreviation "P.C." or alternatively "Service Corporation" or the abbreviation "S.C.". These designations indicate to the public that they are not dealing with a conventional business corporation nor, where the corporate name is composed of the surnames of one or more of the shareholders, are they dealing with a partnership.

It would probably be advisable to require that all proposed corporate names, both at the time of incorporation and on a change of name, must first be approved by the governing body of the particular profession. This would prevent the use of any name which might be considered objectionable by the profession generally. Furthermore it would seem reasonable to require any professional corporation which includes in its name the surname of a former shareholder to obtain the written consent of such former shareholder or his personal representatives.

3. The objects for which the professional corporation is to be established should be limited to the practice of the particular profession (and no other) together with the ownership of investments and such real and personal property as may be incidental to the practice of that profession. Thus a professional corporation would be prohibited from engaging in any transaction which was not compatible with the practice of the profession.

There is no reason why the Act could not provide that certain of the powers set forth in section 19(1) of The Companies Act ${ }^{1 \times}$ would apply to the professional corporation except insofar as the same were expressly excluded by its memorandum of association.

4. Practically all of the professional corporation statutes of the United States require that all directors, officers and shareholders of the corporation must be duly qualified to practise the appropriate profession; furthermore a shareholder must beneficially own all shares registered in his name. At least one of these statutes' ${ }^{1}$ even goes so far as to require, that except in certain enumerated circumstances (such as sickness), all shareholders must be actively engaged in the practice of the profession in the offices of the corporation; however the exact purpose of this requirement is obscure and its adoption is not recommended.

So far as share transfers are concerned, the only restriction should be that the transferee must be a duly licensed practitioner (who does not hold shares in any other professional corporation, or at least in another professional corporation engaged in a different kind of practice). The consent required of the directors or shareholders on a transfer is a matter which can be left to the discretion of the incorporators.

While the requirement that all directors, officers and shareholders must be duly qualified practitioners is a necessary ingredient in any form of professional corporation legislation it does raise at least two major difficulties. In the first case, what is to be done with the shares of a shareholder who is no longer qualified to practise or who dies if his co-shareholders decline to purchase his shares or if he refuses to sell his shares? Secondly how does the "one man firm" incorporate?

With a view to resolving the first mentioned difficulty a number of the statutes in the United States provide that upon the death or 
disqualification of a shareholder his shares must either be purchased or redeemed by the professional corporation or be purchased by others qualified to own shares, in either case within a ninety day period. This is accomplished, in some statutes" $=$ by specifying that in the absence of an agreement between shareholders or of a provision in the corporation's articles of association providing for a transfer of shares within the ninety day period following death or disqualification or if in fact such transfer does not take place within such ninety day period, then it is incumbent upon the corporation to redeem or purchase all of those shares at their book value to be determined as of the end of the month preceding death or disqualification. Book value is to be determined on the basis of the books and records of the corporation in accordance with the regular accounting method adopted by the corporation. Since most professional corporations use the cash method of reporting income (which excludes accounts receivable) the requirement that the purchase price be based upon book value constitutes a strong incentive to shareholders to provide by agreement or by the articles of association for a buy-sell following disqualification or death. For this same purpose other statutes"1 provide that if such shares are not disposed of the professional corporation shall be disqualified from carrying on the professional practice.

A requirement whereby, under certain circumstances, the professional corporation becomes obligated to redeem or purchase its own shares would not only raise tax problems but would also prejudice the rights of the creditors of the corporation, which would not be the case if the existing shareholders were obliged to purchase such shares.

It is suggested that the following provisions be adopted in this Province. Upon the death or disqualification of a shareholder his shares must be transferred to a qualified shareholder within a period of ninety days from death or disqualification; and these shares shall cease to carry any voting rights until transferred." ${ }^{\prime \prime}$ If at the date of death or disqualification there shall be no enforceable agreement or provision in the articles of association of the professional corporation whereby those shares must be sold and transferred, then each of the remaining shareholders shall be required to purchase such shares, on a pro rata basis and for cash, at their fair market value to be determined as at the end of the month immediately preceding death or disqualification. Such determination shall be made by an independent accountant agreeable to all parties concerned. If in fact such transfer shall not be made within such ninety day period then the governing body of the appropriate profession shall have the right, if deemed advisable, to prohibit the professional corporation from practising for such period of time as may be considered appropriate. Provisions such as these would not only recognize the rights of creditors but would also protect the legitimate interests of the surviving shareholders if the failure to transfer shares within the ninety day period arose as a result of some cause beyond their control. Furthermore, the removal of voting rights and the right to participate in the profits of the corporation beyond the

2" Sce for inslance Oklahoma Law's 1961, c. 18, s. 15: Wisconsin Iaws 1961, c. 3j0. s. $10(c)$.

$\because$ See Statutes of Flnridn. c. 621, s. 621.10; Genrgia Laws 1961. Act 285. s. 11

2:- Arizona, Added Laws 1962, c. 53. removes the right to vote until the sharcs have been transferred. 
date of death or disqualification would remove the undesirable consequences of having an unqualified shareholder.

The second mentioned difficulty, namely, how would a "one man firm" incorporate, has been resolved in a number of States":: by permitting a professional corporation to be incorporated with but one shareholder. In other States"' the "one man firm" cannot be incorporated because of the requirement for two or more incorporators.

Once again, existing State legislation fails to provide an altogether acceptable solution for Alberta. On the one hand the one man corporation is too radical a departure from our existing concepts of company organization and existing company legislation, and on the other hand it would be most inequitable to deny to the lone practitioner those advantages which would accrue to him following incorporation.

The most satisfactory solution might well be to permit one voting share (and one only) to be held in trust for the lone practitioner by a non-qualified individual of his choice (as evidenced by a proper declaration of trust). Possibly some restrictions would have to be placed upon this choicc so as to exclude undesirable non-qualified shareholders. This individual would be permitted to be elected as an officer (other than president) and a director of the professional corporation. So as to prevent this non-qualified individual from having any real voice in the conduct of the business of the professional corporation the articles of association of that corporation would be required to contain appropriate provisions whereby in the case of an equality of votes cast at a directors or shareholders meeting, the shareholder qualified to practise the particular profession would have a second or casting vote. Coupled with these provisions would be an automatic termination of the professional corporation's right to practise upon the death or disqualification of the qualified shareholder.

5. Once a decision has been reached as to the degree of personal liability to be imposed upon the shareholders of a professional corporation (and no matter what this degree may be it should exclude the non-qualified shareholder referred to above and also all employees who are not shareholders unless such liability arises as a result of their own negligence) this will have to be set out in detail in the Alberta legislation. On this subject of personal liability it might be useful to review briefly the varying degrees of liability imposed by United States legislation. The statutes of most States provide, in effect, that there shall be no alteration in the existing law applicable to the relationship between a person furnishing a professional scrvice and the recipient of that scrvice (note that this would include such matters as the law relating to privileged communications) including liability arising out of such service. In at least one State, Minnesota, that nothing contained in such section shall render a person liable "in tort" for any act in which he has not personally participated or shall render a director, officer or shareholder personally liable for any contract or obligation made or incurred by him on bchalf of the Company. Another statute:" (presumably out of an abundance of caution) specifically states that the professional corporation shall be liable for any

2: See Pennsylvania Laws 1961. A416. s. 3: Oklahmun Laws 1961, c. 18, s. 4.

-4 Sec Genraia I.aws 1961, Act 285, s. 3: Illinois R.S. 1967. c. 106i-j 2. s. 1.

․: Minnesota Law's 1961. Ex. Sess.. c. 1 , as am. Laws 1963. c. 146.

ai: Statutes of Florida. c. 621, s. 621.07. 
negligent or wrongful acts or misconduct committed by its officers, directors, shareholders or employees. A limited number of statutes ${ }^{2-}$ impose a joint and several liability on all shareholders of the professional corporation for the acts or omissions of any of its employees. Colorado:even goes so far as to permit the articles of incorporation to eliminate this joint and several liability (which is otherwise imposed upon all shareholders) during such periods of time when the corporation shall maintain in good standing "lawyers professional liability insurance" which meets the minimum standards set out in the statute. However it is not clear from an examination of this statute as to whether or not a shareholder would still remain personally liable for his own negligence.

The various professional corporation statutes in force in the United States therefore embrace almost all possible combinations of personal liability except for that of a complete absence of such liability; Opinion 303 of the American Bar Association, referred to earlier, requires that lawyers who render a legal service to a client must be personally responsible to that client.

6. It has already been mentioned that any professional corporation legislation enacted in Canada must make it clear that the professional corporation is entitled to carry on only the practice of the profession. This requirement also applies in the United States-for exactly the same reasons. Sections 6 and 11 of the Oklahoma Act"9 typify the wording employed for the purpose of ensuring that the Internal Revenue Service cannot successfully allege that the income from the practice in reality belongs to the shareholders:

Sec. 6. A professional corporation may be organized pursuant to the provisions of this act only for the purpose of rendering one specific type of professional service and services ancillary thereto. . . .

Sec. 11. A professional corporation may render professional services only through its officers, employees and agents who are duly licensed to render such professional services. ...

As an additional safeguard would it not be prudent to ensure that each employee of the professional corporation, who was a duly qualified practitioner, enters into a written employment contract with the professional corporation?

7. All qualified practitioners employed by a professional corporation would continue to be subject to all relevant statutes, regulations and rules applicable to his profession. The professional corporation likewise would have to comply with certain rules and regulations governing its conduct. For instance the professional corporation should be prohibited from employing in a professional capacity a non-qualified individual and it should also be required to file an annual return with the governing body of the profession setting out the names of all of its officers, directors, shareholders and employees who are employed in a professional capacity.

The purpose of this article is to provide background information on the professional corporation in the hope that it may be of some assistance to the professional man in arriving at an informed opinion as to the desirability, or otherwise, of actively seeking the necessary legislation which would permit him to practise in corporate form. In formulating

2i See Pennsylyania Laws 1961. A 416: Wisconsin Laws 1961. c. 350. s. 8.

:- Statutes of Colorado 1961. c. 22.

20 Oklahoma Laws 1961.. c. 18. 
such an opinion some consideration should be given to the following conclusions which are based upon the material set out above:-

1. The chief advantage which would accrue from the practice in corporate form is that of equality in tax treatment with conventional business conducted in corporate form; this is not to say however that the numerous other advantages should be ignored entirely.

2. While substantial arguments can be advanced both for and against incorporation, based on both historical and ethical considerations, the fact of the matter is that the American Bar Association has concluded that the practice of law by professional corporations does not create ethical problems provided certain safeguards are observed, and the Interim Report of the Ontario Select Committee on Company Law has recommended that legislation be enacted which would permit the incorporation of professional corporations.

3. It would be unrealistic to expect that the revenue authorities in Ottawa will look with favour on the professional corporation, notwithstanding that its use would only have the effect of removing an inequitable and highly artificial disparity in tax treatment. However, there appears to be little likelihood that under existing tax legislation these authorities could successfully deny to the professional corporation those benefits which have been available for many years to the conventional business company.

4. While the Provincial Legislature may well be concerned as to the degree of personal liability to be imposed upon the shareholders of the professional corporation, there is no valid reason why it should not give sympathetic consideration to a request for a Professional Corporations Act so long as reasonable safeguards are included for the protection of the general public and for the continued control of the individual members of the profession.

5. While certain technical difficulties may well arise during the actual drafting of the enabling legislation, none of these difficulties should prove insurmountable. In large measure these same difficulties have already been faced by draftsmen in the United States and they have apparently been satisfactorily resolved.

6. If enabling legislation is ultimately introduced in this Province the professional man would be well advised to proceed cautiously and satisfy himself, prior to incorporation, as best he is able that the professional corporation will best serve his particular needs. 